\title{
Relationship between magnetic properties and reddening of tropical soils as indicators of weathering
}

Holger Preetz ${ }^{1,2}$, Jan Igel ${ }^{1 *}$, Jacqueline A. Hannam ${ }^{3}$, Susanne Stadler ${ }^{4}$

${ }^{1}$ Leibniz Institute for Applied Geophysics, Stilleweg 2, D-30655 Hannover, Germany, jan.igel@liag-hannover.de

${ }^{2}$ now at: Federal Competence Center for Soil and Groundwater Protection / UXO Clearance, Hannover, Germany

${ }^{3}$ School of Water, Energy and Environment, Cranfield University, Cranfield, MK43 0AL, U.K.

${ }^{4}$ Federal Institute for Geosciences and Natural Resources (BGR), Stilleweg 2, D-30655 Hannover, Germany

*Corresponding author

\begin{abstract}
This study evaluates the use of magnetic properties as an indicator of weathering of tropical soils. Soil samples collected across the tropical belt were analysed for magnetic susceptibility and its frequency dependence. Frequency dependence is caused by superparamagnetic (SP) ferrimagnetic nanoparticles, which are commonly attributed to neoformation during soil forming processes. Magnetic properties are compared to the redness rating of soil colour, which is related to the hematite content and is an established proxy for soil weathering. The investigated samples comprise material of different weathering stages from unweathered and weathered rock to subsoil and strongly weathered topsoil. They cover a broad variety of parent materials: ultrabasic, basic, intermediate, acid igneous rocks, clays and clay slates, phyllites
\end{abstract}


and sandstones. The results show that soil reddening, magnetic susceptibility and in particular frequency-dependent susceptibility generally increase with proceeding weathering. However, there is a lithologic overprint and the parent material has to be taken into consideration. Soils stemming from acid igneous rocks, clays, clay slates and phyllites show a positive correlation between reddening and susceptibility or frequency dependent susceptibility, rendering these properties suitable for indicating weathering. In contrast, soils stemming from ultrabasic, basic and intermediate igneous rocks and sandstones show no significant correlation. The reason is the strong lithogenic overprint of ferrimagnetic minerals including SP particles, which commonly occur in these rock types.

Keywords: tropical soil; laterite; soil development; iron oxide; reddening; magnetic susceptibility

\section{Introduction}

\subsection{Lateritic soil formation}

Laterites, (ferralsols, plinthosols or oxisols FAO, 2006; NRCS, 2006) are one of the most widespread soil types in the humid tropics. They are the outcome of long-lasting and intense chemical weathering processes under humid conditions under variable soil moisture regimes. Laterites are generally characterised by the following features: strong weathering of silicates; the release of $\mathrm{Fe}$ and $\mathrm{Al}$ ions forming new minerals such as gibbsite and $\mathrm{Fe}$ oxides (predominatly goethite and hematite) (Tardy and Roquin, 1992) and the prevalence of kaolinite. Laterites are formed from different geologies (e.g. silicate rocks and limestone) and their composition and properties are strongly controlled by the chemical composition of the parent rock (Schellmann, 1981). 


\subsection{Reddening}

Hematite is a main constituent of lateritic soils and is responsible for their characteristic red colour (Torrent et al. 1983; Fontes and Carvalho 2005), and is an indicator of weathering state (Schwertmann, 1993). The neoformation of hematite from the dehydration of ferrihydrite requires elevated soil temperatures and low water activity (Schwertmann, 1993). Typical laterites are therefore different to strongly weathered soils under permanent humid soil moisture regimes which favour goethite over hematite formation (Fontes and Carvalho, 2005), where in this case, hematite content is not a suitable proxy for weathering. The verification of the paragenetic formation of maghemite and hematite was accomplished by Torrent et al. (2006, 2010a).

\subsection{Soil magnetic susceptibility}

Soil magnetic susceptibility is caused by the presence of ferrimagnetic $\mathrm{Fe}$ and $\mathrm{Fe} / \mathrm{Ti}$ Oxides such as magnetite, titanomagnetite and maghemite that are stable in soils and can accumulate due to their resistance to weathering. The absolute value of susceptibility is proportional to the amount of ferrimagnetic minerals and is also influenced by the mineral particle size. Grain sizes depend on the provenance and conditions of formation. Macro-sized multidomain (MD) ferrimagnetic minerals tend to be of lithogenic origin (formed during the crystallisation of igneous rocks), derived from the weathering of ultrabasic and basic igneous rocks. In contrast, ultrafine grained ferrimagnetic minerals are thought to form mainly during pedogenesis (Maher and Taylor, 1988). These minerals are superparamagnetic (SP) and show frequencydependence of magnetic susceptibility. This behaviour is based on the relaxation of the SP minerals which gives rise to a time decay of magnetisation termed magnetic viscosity (Néel, 
1949). Thus, quantifying this property can potentially provide a proxy for soil formation and weathering in certain environments.

\subsection{Ferrimagnetic mineral formation and co-formation of hematite}

Ferrimagnetic minerals of pedogenic origin form during weathering and soil genesis by geochemical or bacterial processes. There are several theories describing these processes. The first describes ferrihydrite transforming to magnetite via partial dehydration and oxidation in the presence of excess $\mathrm{Fe}^{2+}$ ions in solution (Schwertmann, 1988; Dearing et al., 1996). Subsequently, magnetite may oxidise to maghemite. This pathway requires the sufficient release of Fe from the parent material through hydrolysis and subsequent dissolution by $\mathrm{Fe}$ reducing bacteria. When a critical concentration of $\mathrm{Fe}^{2+}$ is reached, it will be oxidised. These transformations are facilitated by wetting and drying cycles in soils with corresponding changes in water activity, $\mathrm{pH}$ and redox conditions.

A second theory assumes pedogenic enhancement of ferrimagnetic minerals in tropical and subtropical soils also occurs in conjunction with pedogenic hematite formation (Torrent et al. 2006). Warm to hot and sub-humid to humid climates favour the dehydration that is necessary to transform ferrihydrite to hematite (Schwertman, 1988). The model suggests transformation occurs with intermediate steps producing ferrimagnetic minerals : ferrihydrite - SP (superparamagnetic) maghemite (i.e. nanosized ferrimagnetic minerals) - SD (ferrimagnetic single domain) maghemite - hematite (Torrent et al., 2006). The intensity of each step of the pathway varies according to the pedoclimate and degree of weathering. This means that rates of ferrihydrite and maghemite formation are relatively fast compared to hematite formation in permanently moist but not saturated soils. In contrast, tropical soils undergoing seasonal drying tend to exhibit a faster hematite formation. However, Torrent et al. (2010b) stress that such 
processes are highly complex and should be carefully evaluated and compared only when formed on similar parent materials.

The transformation pathways for ferrimagnetic minerals and hematite are in agreement with the general conditions that favour the formation of laterites where various mechanisms of hydration and dehydration create sequences of minerals in different hydration states (Tardy and Roquin 1992). Thus laterites provide a key environment to investigate the use of magnetic measurements as indicators of soil formation and development.

While it is common to regard the visible Fe oxides such as hematite and goethite as products and indicators of soil development it is still rare to use the ferrimagnetic iron oxides for that purpose. It has been demonstrated that the presence of the magnetic iron oxide fraction of soils is also a widespread phenomenon that responds to and reflects soil forming processes (Mullins (1977); Maher (1986). The advantage of using magnetic susceptibility as an indicator for soil development is that this property provides a quantitative measure of the amount of ferrimagnets and is relatively easy to measure.

Many investigations of magnetic properties have been conducted in soils of temperate or subtropical regions, only very few analyses are available for tropical soils. It is generally assumed that an increase in soil magnetic susceptibility occurs with an increasing age of the soil and with climate being warmer and wetter (cf. Singer et al., 1996; Torrent et al., 2010a). Therefore deeply weathered lateritic soils are suitable environments to verify the relationship between soil formation and soil magnetic properties.

The aim of this study is to i) investigate the potential of ferrimagnetic compounds as a proxy for soil formation and weathering in tropical environments, ii) identify if magnetic susceptibility is a result of pedogenic neoformation or if there is a significant lithogenic 
overprint and iii) investigate the relationship between soil reddening and magnetic susceptibility according to different parent rock types.

\section{Materials and Methods}

\subsection{Soil samples}

The soil samples originate from the geoscientific collection of the Federal Institute for Geosciences and Natural Resources (BGR) in Hanover, Germany. The sample collection ( $\mathrm{n}=$ 1475 samples) includes lateritic soils and their siliciclastic parent material from tropical regions. Samples were collected from the field at the beginning of the 1970s. These laterites are classified as Ferralsols and Plinthosols (FAO, 2006) or Oxisols (NRCS, 2006). The samples were originally collected to investigate mineral alterations under intense tropical weathering and the genesis of mineral deposits (Schellmann, 1974). At the time of collection the samples were air-dried, mechanically crushed to $<2 \mathrm{~mm}$ and homogenised. Since preparation they have been stored in an air-dried state in the sample archive of the BGR in plastic boxes under constant indoor climate.

A sub-set of 506 samples was selected and includes topsoil and subsoil from various depths, in addition to weathered and unweathered parent rocks (Table 1). Table 1 also lists the countries of origin of the samples and parent rock type based on the original field description. The classification of the igneous rocks was made by consulting available geochemical data of the samples which resulted in basic gabbro being classified as ultrabasic.

2.2 Determination of magnetic susceptibility 
Measurements of volume-specific magnetic susceptibility $\kappa$ were conducted using a MS2B sensor (Bartington Instruments, Witney, UK ;Dearing, 1999). The dry homogenised soil samples were filled into $10 \mathrm{ml}$ plastic boxes and measured at two frequencies (LF: $465 \mathrm{~Hz}$ and HF: $4.65 \mathrm{kHz}$ ) at a magnetic field strength of approximately $\mathrm{H}=80 \mathrm{~A} / \mathrm{m}$. Each sample was measured ten times to ensure high reproducibility and the mean value was used for further analysis. In addition, the filling levels of the boxes were measured and the susceptibility results were adjusted according to the sample volume (Preetz et al., 2008). Volume-specific susceptibility $\kappa$ was transformed into mass-specific susceptibility $\chi$ by dividing by the sample bulk density.

\subsection{Determination of soil colour}

Most soils containing hematite have Munsell hues between 5YR and 10R. The occurrence of these colours usually relate to the state of weathering due to the pigmenting power of hematite (Schwertmann, 1993).

The colours of the dry and homogenised soil samples were visually determined using the “Munsell Soil Color Charts" (Munsell Color Company, 1975). The determination was carried out by two independent observers under controlled lighting conditions by the use of a natural light lamp with a colour temperature of $6500 \mathrm{~K}$ and a spectral composition equal to natural light. The resulting Munsell values were transformed to a redness rating $(R R)$ originally developed by Torrent et al. (1980) as a measure for the intensity of reddening. It is expressed as follows: $R R=(10-H) \cdot C / V$, with $H=$ hue, $C=$ chroma and $V=$ value. Whilst this method is subjective it was selected so that redness could be determined by any observer without the need for a spectrophotometer and can also be applied to standard field description of soils where a Munsell colour has been recorded in the absence of actual samples. 
A comparison of the colour determination by the two individual observers is given in Figure 1. Both results correspond well and demonstrate the reproducibility of the method. For further analysis, the mean of both individual results is used.

\subsection{Geochemical analysis}

Geochemical analysis of the samples was accomplished using X-ray fluorescence (XRF) with a Philips spectrometer PW 1220. The samples were prepared by melting with a flux (1 part of sample and 5 parts of Li-metaborate) at $1250{ }^{\circ} \mathrm{C}$, and international standards were used for calibration (Schellmann, 1986).

\section{Results and discussion}

The samples were grouped according to their parent material and each group was further subdivided according to the degree of weathering into unweathered parent material, weathered parent material, subsoil and topsoil (Table 1). Generally there is a trend for increasing lowfrequency magnetic susceptibility $\left(\chi_{\mathrm{LF}}\right)$, frequency-dependent magnetic susceptibility $(\Delta \chi)$ and redness rating $(\mathrm{RR})$ from the parent rock to the soil (i.e. as weathering increases) on all rock types (Figure 2). Although the magnitude of the enhancement varies between the different parent material types. Fe contents are highest for ultrabasic and basic parent rock material (Figure 2) and increase with ongoing weathering, reaching up to $63 \%$ for soils stemming from ultrabasic rocks.

3.1 Ultrabasic and basic/intermediate parent rocks 
Material derived from ultrabasic and basic/intermediate parent rocks generally show higher susceptibilities than the other samples with median values $>800 \times 10^{-8} \mathrm{~m}^{3} / \mathrm{kg}$ (Figure 2, Table 2) and there is no significant correlation between LF susceptibility and RR (Figure 3) or between FD susceptibility and RR (Figure 4). These soils also show low enrichment factors in magnetic susceptibility (Table 2), particularly for the basic/intermediate rocks where there is little difference between the soil and parent material. These samples also show frequency dependence of susceptibility in the soil and rock samples. The unweathered parent materials also have high susceptibilities (median 341 and $547 \times 10^{-8} \mathrm{~m}^{3} / \mathrm{kg}$ for ultrabasic and basic/intermediate rocks, respectively) indicating a significant ferrimagnetic mineral concentration in the parent rock.

Magnetite and titanomagnetite are ubiquitous minerals in these rock types and are typically concentrated in the stable heavy metal fraction of tropical soils (Kanig, 1990). This results in enhancement of frequency-dependent magnetic susceptibility and in the case of soils from ultrabasic rock also the low-frequency susceptibility from residual enrichment of weatheringresistant magnetite/titanomagnetite of all grain sizes (MD, SSD and SP). The general stability of magnetite, similar to that of hematite, has also been identified in Mediterranean soils (Di Figlia et al. 2007). SP minerals are typically thought to be an indicator of pedogenic processes but they can appear in volcanic rock itself, formed from a short crystallisation phase during very rapidly cooling of magma. Hence, they can preferably occur in volcanic rocks such as glasses and basalts (Zhou et al., 2000; Knudsen et al., 2005). This questions the use of FD susceptibility as suitable proxy for tropical soil development on these parent material types because the SP minerals can also be of lithogenic origin.

The lithogenic input of coarser ferrimagnetic particles can further contribute to the increase of frequency-dependent susceptibility via the disintegration of MD and SSD particles rather than 
neoformation of SP particles. Comminution of lithogenic MD particles by weathering (Maher 1998) may be intensified in laterites due to the long timescales of weathering. During the process of comminution, less hematite seems to be formed than during the inorganic neoformation of SP minerals, which would explain the low correlation of $\chi_{\mathrm{LF}}$ or $\Delta \chi$ with RR for the group of ultrabasic, basic and intermediate rocks.

\subsection{Acid igneous rocks}

Topsoils developed on acid igneous rocks have moderate susceptibility (median $\chi_{\mathrm{LF}} 94 \times 10^{-8}$ $\mathrm{m}^{3} \mathrm{~kg}^{-1}$ ) and low concentrations of SP minerals (median $\Delta \chi 3.8 \times 10^{-8} \mathrm{~m}^{3} \mathrm{~kg}^{-1}$ ) (Table 2). There is a weak positive correlation between magnetic parameters and RR (Figures 3 and 4). This weak positive correlation between $\mathrm{RR}$ and $\chi_{\mathrm{LF}}$ and $\Delta \chi$ indicate a relationship between the neoformation of ferrimagnets in the SP grain size and the formation of hematite. Since acid rocks commonly only contain small proportions of magnetite a residual enrichment mechanism for the enhanced magnetic susceptibility can be excluded. There is also a higher AF for $\Delta \chi$ susceptibility than for $\chi_{\mathrm{LF}}$ (Table 2), supporting the assumption of neoformation of ferrimagnetic minerals over a lithogenic input.

\subsection{Clay and clay slates}

Topsoils developed on clays have moderate susceptibility (median $\chi_{\mathrm{LF}} 189 \times 10^{-8} \mathrm{~m}^{3} \mathrm{~kg}^{-1}$ ) and moderate concentrations of SP minerals (median $\Delta \chi 8.4 \times 10^{-8} \mathrm{~m}^{3} \mathrm{~kg}^{-1}$ ) (Table 2). There is a clear separation between the magnetic susceptibility of the parent material and soil (Figure 2) also indicated by an enhanced accumulation factor (Table 2). There is a strong correlation between RR and magnetic properties in soils developed from clays and clay slates. Compared 
to soils on basic and ultrabasic rocks there is a greater differentiation between the soil and parent material magnetic susceptibility and a moderate enhancement of $\Delta \chi$ that is also positively correlated with RR.

Although the soils developed from clays were subject to similar chemical weathering to the other parent material groups the increase of frequency-dependent susceptibility and RR in weathered claystones and slates suggests that neoformation of SP minerals already occurs in early stages of the laterisation process. This indicates the dominant mechanism is neoformation of ferrimagnetic minerals for magnetic enhancement in these soils.

The model of neoformation of Dearing et al. (1996) might be assumed since preconditions such as a cyclic change of redox conditions, which provide sufficient Fe supply and dehydration and oxidation cycles, prevail for laterites. It could be argued that these highly weathered soils do not provide sufficient primary Fe-bearing minerals (as the source material of $\mathrm{Fe}^{2+}$ ) required for the formation of ferrihydrite, the precursor for magnetite. In soils formed in the Tertiary red clay in the Chinese Loess plateau a decline of ferrimagnetic minerals with corresponding enhancement of hematite was found with increasing soil development (Hu et al. 2009). This was attributed to the ferrimagnetic phase transforming into hematite during aging of Fe oxides (cf. Torrent et al., 2006). However, laterites are developed under different conditions to the soils of the Chinese Loess Plateau, and these conditions provide enough opportunities for a repeated Fe release from weathering of primary and secondary Fe minerals. Thus the continued production of neoformed ferrimagnetic minerals could occur.

The correlation of RR with low frequency and frequency-dependent susceptibility corresponds to the formation model of Torrent et al. (2006) where ferrihydrite is transformed by dehydration to maghemite that subsequently oxidises to hematite. The first step is faster than the second. It is also coupled to soil conditions remaining moist, but not saturated most of the year and warm 
enough for substantial mineral transformation. These conditions are typical for the investigated lateritic soil types.

\subsection{Phyllite rocks}

Results for soils from phyllites should be interpreted with caution due to small sample numbers $(\mathrm{n}=21)$. Phyllites are formed during low-grade regional metamorphism of predominantly clay slates and other clayey sediments so they provide comparable conditions for tropical soil formation as the clay/clay slate group. They also show a trend towards increasing $\chi_{\mathrm{LF}}, \Delta \chi$ and RR with weathering intensity (Figure 2 ). The topsoil samples $(n=2)$ have high $\chi_{\mathrm{LF}}$ (median $1264 \times 10^{-8} \mathrm{~m}^{3} \mathrm{~kg}^{-1}$ ), subsoil samples also show enhancement of susceptibility (Table 2). Samples also show a positive but slightly weaker correlation between RR and $\chi_{\mathrm{LF}}$ and $\Delta \chi$ than the clay/clay slate sediments (Figures 3 and 4). Based on the discussion above we conclude that enhanced magnetic susceptibility in combination with increased reddening in laterites developed from phyllites is mainly due to pedogenic neoformation. Lithogenic ferrimagnets inherited from parent material may play a minor role.

\subsection{Sandstone}

The number of laterite samples derived from sandstone is low $(n=19)$ but the results provide an indication of increased $\chi_{\mathrm{LF}}$ and $\Delta \chi$ with weathering intensity (Figure 2). However there is little correlation between the magnetic properties and RR (Figures 3 and 4). This lack of reddening and increase in SP minerals during soil genesis suggests either a dominant lithogenic input for the origin of the magnetic minerals or soil conditions are less conducive to the formation of ferrimagentic minerals. In soils derived from sandstones ferrimagnetic particles 
can be detrital, stemming from fresh rocks of the source area of the sediments and/or from pedogenic processes that take place before the material was eroded and deposited (Hounslow, 1996; Maher and Taylor, 1988; Von Suchodoletz et al. 2009). Moreover, magnetite is often concentrated as a placer deposit along the border of shorelines which is conserved in the resulting sediments. Although our data set is too small for general conclusions in this context, it provides evidence that lithogenic inputs into magnetic compounds of tropical soils could also occur from acid clastic sediments.

\section{Summary and conclusions}

The relationship between reddening (as redness rating $R R$ ) and magnetic properties (low frequency magnetic susceptibility $\chi_{\mathrm{LF}}$ and frequency dependent magnetic susceptibility $\left.\Delta \chi\right)$ was investigated for its potential as a proxy for characterising weathering and environmental conditions of tropical soil formation. All of the investigated samples belong to the same general soil type and were therefore subject to comparable environmental and soil forming conditions such as changes in wetting and drying, and related redox potential changes.

The data indicates that given sufficient Fe supply magnetic susceptibility increases with increasing soil age (Boyle et al., 2010) and with weathering regimes with increasing temperature and moisture (Singer et al., 1996). However, this relationship has limitations because the underlying mechanisms of magnetic enhancement show differences depending on the nature of the parent rock. The dataset does not support a universal pathway of magnetic enhancement for all laterite soils. Parent rock is shown to have a strong influence on the chemical composition of lateritic soils (Schellmann, 1986), causing differentiation between lateritic soils on different patent materials. 
The following conclusions can be drawn regarding our results of $\mathrm{RR}$ and magnetic properties being used as proxies for soil development stages in lateritic soils:

i) The enhancement of ferrimagnetic minerals in tropical soils deriving from ultrabasic and basic/intermediate rocks is due to a strong lithogenic overprint. Thus magnetic measurements in these soils are not useful proxies for neoformed pedogenic ferrimagnetic minerals and corresponding soil development. The enrichment of weathering-resistant ferrimagnetic iron oxides is concordant with lateritic processes and enrichment of certain elements such as Al (Schellmann, 1981).

ii) Soils stemming from clay and clay slate, phyllite and acid igneous rocks show a strong positive correlation between RR and magnetic susceptibility and indicate neoformation of SP ferrimagnetic minerals, thus making these measurements a suitable proxy for soil development in these soils. Pedogenic hematite has been suggested to derive from the transformation of ferrimagnetic minerals. If this were the case as hematite content increases, magnetic properties should decrease, which has not been shown in these samples. The coexistence of hematite and ferrimagnetic minerals after such long weathering histories in laterites suggest that other pathways may take place during tropical weathering and laterite formation. In laterites derived from clay substrates two phases (detrital and secondary) of kaolinite have been observed (Balan, et al., 2007). This suggests long-term active phases of dissolution and neoformation are evident in laterites on these substrates and these processes could also be relevant for the continued production of pedogenic ferrimagnetic minerals over long weathering timescales.

Further investigations should address if the stability of SP minerals that stem from neoformation are similar to lithogenic sources. This could provide fundamental information to identify the different origins for magnetic enhancement in tropical soils and the subsequent reliability as a soil development index in lateritic soils. 


\section{Acknowledgements}

This work has in part been supported by the Federal Ministry of Education and Research (BMBF) and the Federal Ministry of Defence, Germany. We thank T. Putzmann H. Schröder,

D. Renk and K. Haase for carrying out the susceptibility measurements and determining the sample colours. 


\section{References}

Balan, E., Fritsch, E., Allard, T., Calas, G., 2007. Inheritance vs. neoformation of kaolinite during lateritic soil formation: A case study in the middle Amazon basin. Clays and Clay Minerals, 55: 253-259

Boyle, J.F., Dearing, J.A., Blundell, A., Hannam, J.A., 2010. Testing competing hypotheses for soil magnetic susceptibility using a new chemical kinetic model. Geology, 38: 10591062.

Dearing, J.A., 1999. Environmental magnetic susceptibility - Using the Bartington MS2 system. Chi publishing, Kenilworth.

Dearing, J.A., Hay, K.L., Baban, S.M.J., Huddleston, A.S., Wellington, E.M.H., Loveland, P.J., 1996. Magnetic susceptibility of soil: an evaluation of conflicting theories using a national data set. Geophys. J. Int., 127: 728-734.

Di Figlia, M.G., Bellanca, A., Neri, R., Stefansson, A., 2007. Chemical weathering of volcanic rocks at the island of Pantelleria, Italy: Information from soil profile and soil solution investigations. Chemical Geology, 246: 1-18.

FAO (Food and Agriculture Organization of the United Nations), 2006. World reference base for soil resources 2006 - a framework for international classification, correlation and communication. World soil resources reports. 103. Rome. Available at www.fao.org/ag/Agl/agll/wrb/doc/wrb2006final.pdf

Fontes, M.P.F., Carvalho, I.A., 2005. Color attributes and mineralogical characteristics, evaluated by radiometry, of highly weathered tropical soils. Soil Sci. Soc. Am. J., 69: 11621172.

Hounslow, M. W., 1996. Ferrimagnetic Cr and Mn spinels in sediments: Residual magnetic minerals after diagenetic dissolution, Geophys. Res. Lett., 23(20), 2823-2826. 
Hu, X.-F., Xu, L.-F., Pan, Y., Shen, M.-N., 2009. Influence of the aging of Fe oxides on the decline of magnetic susceptibility of the Tertiary red clay in the Chinese Loess Plateau. Quat. Int., 209, 22-30.

Kanig, M., 1990. Lateritische Verwitterungsdecken im Bereich des Alkalikomplexes von Jacupiranga, Sao Paulo, Brasilien.- Mitteilungen zur Mineralogie und Lagerstättenkunde, 35: 260 pp., PhD thesis RWTH Aachen University.

Knudsen, M. F., Abrahamsen, N., Riisager, P., 2005. A rock- and palaeomagnetic study of geologically recent lavas and 1995 volcanic glass on Fogo (Cape Verde Islands), Bulletin of the Geological Society of Denmark, 52, 39-52.

Maher, B.A., 1986. Characterisation of soils by mineral magnetic measurements. Phys. of the Earth and Plan. Int. 42: 76-92.

Maher, B.A., Taylor, R.M., 1988. Formation of ultrafine-grained magnetite in soils. Nature, 336: $368-370$.

Maher, B. A., 1998. Magnetic properties of modern soils and Quaternary loessic paleosols: paleoclimatic implications. Palaeogeography, Palaeoclimatology, Palaeoecology 137, 2554.

Mullins, C.E., 1977. Magnetic susceptibility of the soil and its significance in soil science - a review. J. Soil Sci. 28: 223-246.

Munsell Color Company, 1975. Munsell Soil Color Charts. Macbeth Division of Kollmorgen, Baltimore, MD.

Néel, L., 1949. Théorie du traînage magnétique des ferromagnétiques en grains fins avec applications aux terres cuites. Annales de Géophysique, 5: 99-136.

NRCS (Natural Resources Conservation Service), 2006. Keys to Soil Taxonomy, 10th edn, NRCS, Washington, DC. Available at: soils.usda.gov/technical/classification/taxonomy/ 
Preetz, H., Altfelder, S., Igel, J., 2008. Tropical Soils and Landmine Detection-An Approach for a Classification System. Soil Sci. Soc. Am. J., 72:1, 151-159.

Schellmann, W., 1974. Abschlussbericht zum Forschungsvorhaben Nr. 1630 "Laterit", Teil 1: Allgemeine Forschungsergebnisse. Archive report, Federal Institute for Geosciences and Natural Resources (BGR), Hannover.

Schellmann, W., 1981. Considerations on the definition and classification of laterites. Lateritisation processes, proceedings of the international seminar on lateritisation processes, Trivandrum/India: pp 1-10.

Schellmann, W., 1986. On the Geochemistry of Laterites. Chem. Erde 45: 39-52.

Schwertmann, U., 1988. Occurrence and formation of iron oxides in various pedoenvironments. p. 267-308. In: Stucki, J.W., B.A. Goodman, and U. Schwertmann. (eds.) Iron in soils and clay minerals. Reidel, Dordrecht.

Schwertmann, U., 1993. Relations between iron oxides, soil color, and soil formation. In: Bigham, J.M. \& Ciolkosz, E.J. (eds.) "Soil color". Soil Sci. Soc. Am. Spec. Publ. 31:5169.

Singer, M.J., Verosub, K.L., Fine, P., TenPas, J., 1996. A conceptual model for the enhancement of magnetic susceptibility in soils. Quat. Int., 34-36: 243-248.

Tardy, Y., Roquin, C., 1992. Geochemistry and evolution of lateritic landscapes.- In. Martini, I.P. \& Chesworth, W. (eds.): Weathering, soils and paleosols - Developments in earth surface processes 2: 407-443. Elsevier.

Torrent, J., Schwertmann, U., Schulze, D.G., 1980. Iron oxide mineralogy of some soils of two river terrace sequences in Spain, Geoderma, 23: 191-208.

Torrent, J., Schwertmann, U., Fechter, H., 1983. Quantitative relationships between soil color and hematite content. Soil Sci. 136:354-358. 
Torrent, J., Barrón, V., Liu, Q., 2006. Magnetic enhancement is linked to and precedes hematite formation in aerobic soil. Geophys. Res. Lett., 33: 4 pp, doi:10.1029/2005GL024818.

Torrent, J., Liu, Q. S., Barrón, V., 2010a. Magnetic susceptibility changes in relation to pedogenesis in a Xeralf chronosequence in northwestern Spain. European Journal of Soil Science, 61: 161-173.

Torrent, J., Liu, Q. S., Barrón, V., 2010b. Magnetic minerals in Calcic Luvisols (Chromic) developed in a warm Mediterranean region of Spain: Origin and paleoenvironmental significance. Geoderma, 154: 465-472.

Von Suchodoletz, H., Kühn, P., Hambach, U., Dietze, M., Zöller, L., Faust, D., 2009. Loesslike and palaeosol sediments from Lanzarote (Canary Islands/Spain) - Indicators of pelaeoenvironmental change during the Late Quaternary. Palaeogeography, Palaeoclimatology, Palaeoecology, 278: 71-87.

Zhou, W., Van der Voo, R., Peacor, D. R., Zhang, Y., 2000. Variable Ti-content and grain size of titanomagnetite as a function of cooling rate in very young MORB, Earth and Planetary Sci. Lett., 179, 9-20. 


\section{Tables}

Table 1: Overview of the investigated material, including number of samples, country of origin and parent rock material. Ultrabasic igneous rocks: gabbro, phonolite, serpentinite; Basic and intermediate igneous rocks: amphibolite, andesite, basalt, olivine-feldspar-basalt, charnockite, diabase, dolerite, gabbro, gneiss, phonolite; Acid igneous rocks: charnockite, dolerite, gneiss, biotite-gneiss, granitic gneiss, granite; Clays/clay slates: pisolite, slate, shale, quartzitic slate, clay slate, carbonaceous clay, tertiary sediments; Phyllites: phyllite; Sandstones: sandstone, quartzite.

\begin{tabular}{|c|c|c|c|c|c|c|c|}
\hline Origin & Ultrabasic & $\begin{array}{l}\text { Basic } \\
\text { Inter- } \\
\text { mediate }\end{array}$ & Acid & $\begin{array}{l}\text { Clay/ } \\
\text { Clay slates }\end{array}$ & Phyllites & $\begin{array}{l}\text { Sand- } \\
\text { stones }\end{array}$ & $\Sigma$ \\
\hline Australia & & 9 & 39 & 26 & & 10 & 84 \\
\hline Brazil & 21 & 30 & 9 & 11 & 14 & & 85 \\
\hline El Salvador & & 10 & & & & & 10 \\
\hline Ghana & & & 17 & 10 & 7 & 9 & 43 \\
\hline Guatemala & 8 & & & & & & 8 \\
\hline Hawaii & & 19 & & & & & 19 \\
\hline India & & 9 & 36 & 10 & & & 55 \\
\hline Madagascar & 15 & 16 & 16 & & & & 47 \\
\hline Mexico & & & 4 & & & & 4 \\
\hline $\begin{array}{l}\text { New } \\
\text { Caledonia }\end{array}$ & 20 & & & & & & 20 \\
\hline Philippines & 8 & & & & & & 8 \\
\hline Puerto Rico & 21 & 4 & & & & & 25 \\
\hline Sri Lanka & & 4 & 20 & & & & 24 \\
\hline Uganda & & 8 & 22 & 16 & & & 46 \\
\hline Venezuela & 13 & 8 & 7 & & & & 28 \\
\hline$\Sigma$ & 106 & 117 & 170 & 73 & 21 & 19 & 506 \\
\hline
\end{tabular}


Table 2: Median values of magnetic susceptibility $\chi_{\mathrm{LF}}$, frequency dependence $\Delta \chi$, redness $\mathrm{RR}$ and iron content and correlation coefficients $r$. The level of significance of $r$, the probability of error $\alpha$, has been determined by a Student's t-test. Accumulation factors (AF) represent the ratio between the median values of the topsoil samples and the median values of the unweathered parent rocks. 


\begin{tabular}{|c|c|c|c|c|c|c|c|c|c|c|c|c|c|c|}
\hline rock group & material & $\begin{array}{c}\text { number of } \\
\text { samples }\end{array}$ & $\begin{array}{c}\chi_{\text {LF }}\left[10^{-8}\right. \\
\left.\mathbf{m}^{3} / \mathbf{k g}\right]\end{array}$ & $\underset{[-]}{\mathbf{A F}(\chi \mathbf{L F})}$ & $\begin{array}{l}\Delta \chi\left[10^{-8}\right. \\
\left.\mathbf{m}^{3} / \mathbf{k g}\right]\end{array}$ & $\begin{array}{c}\mathbf{A F}(\Delta x)\left[10^{-8}\right. \\
\left.\mathbf{m}^{3} / \mathbf{k g}\right]\end{array}$ & \begin{tabular}{||l} 
RR I- \\
l
\end{tabular} & $\underset{[-]}{\mathbf{A F}(\mathbf{R R})}$ & $\begin{array}{c}\mathrm{Fe}_{2} \mathrm{O}_{3} \\
{[\%]}\end{array}$ & $\underset{[-]}{\mathbf{A F}\left(\mathrm{Fe}_{2} \mathbf{O}_{3}\right)}$ & $\begin{array}{l}\mathbf{r}(\mathbf{R R} \text { vs. } \\
\left.\lg \left(\chi_{\mathrm{LF}}\right)\right)[-]\end{array}$ & $\begin{array}{c}\alpha \\
{[\%]}\end{array}$ & $\begin{array}{l}\mathbf{r}(\mathbf{R R} \text { vs. } \\
\lg (\Delta x))[-]\end{array}$ & $\begin{array}{c}\alpha \\
{[\%]}\end{array}$ \\
\hline \multirow[t]{5}{*}{ ultrabasic } & all & 106 & 1589 & \multirow{5}{*}{5.6} & 15 & \multirow{5}{*}{23.5} & 11.8 & \multirow{5}{*}{3.5} & 58.9 & \multirow{5}{*}{6.4} & 0.14 & $<20$ & 0.14 & $<<20$ \\
\hline & topsoil & 17 & 1906 & & 47 & & 12 & & 63.3 & & 0.13 & $>50$ & -0.1 & $>50$ \\
\hline & subsoil & 53 & 2514 & & 41 & & 12.5 & & 63.4 & & -0.41 & $<1$ & -0.56 & $<1$ \\
\hline & $\begin{array}{l}\text { weath. } \\
\text { rock }\end{array}$ & 28 & 384 & & 2.7 & & 9.3 & & 20.3 & & 0.05 & $>50$ & 0.21 & $>20$ \\
\hline & unw. rock & 8 & 341 & & 2.0 & & 3.4 & & 9.9 & & -0.07 & $>50$ & -0.27 & $>50$ \\
\hline \multirow{5}{*}{$\begin{array}{l}\text { basic / } \\
\text { intermediate }\end{array}$} & all & 117 & 820 & \multirow{5}{*}{1.4} & 7.0 & \multirow{5}{*}{15.0} & 9 & \multirow{5}{*}{3.7} & 23.7 & \multirow{5}{*}{1.9} & -0.06 & $>50$ & 0.15 & $<20$ \\
\hline & topsoil & 23 & 793 & & 15 & & 10 & & 27.4 & & -0.39 & $<10$ & -0.21 & $>20$ \\
\hline & subsoil & 38 & 584 & & 7.1 & & 8.9 & & 27.5 & & -0.14 & $>20$ & -0.25 & $<20$ \\
\hline & $\begin{array}{l}\text { weath. } \\
\text { rock }\end{array}$ & 41 & 972 & & 7.0 & & 9.3 & & 22.9 & & -0.15 & $>20$ & 0.05 & $>50$ \\
\hline & $\begin{array}{l}\text { Tock } \\
\text { unw. rock }\end{array}$ & 15 & 547 & & 1.0 & & 2.7 & & 14.5 & & -0.2 & $>20$ & 0.25 & $>20$ \\
\hline \multirow[t]{5}{*}{ acid } & all & 170 & 34 & \multirow{5}{*}{5.5} & 1.6 & \multirow{5}{*}{19} & 7.2 & \multirow{5}{*}{2.2} & 8.45 & \multirow{5}{*}{4.9} & 0.30 & $<1$ & 0.51 & $<1$ \\
\hline & topsoil & 36 & 94 & & 3.8 & & 8.3 & & 13.1 & & 0.28 & $<10$ & 0.30 & $<10$ \\
\hline & subsoil & 74 & 41 & & 2.4 & & 7.5 & & 13.8 & & 0.40 & $<1$ & 0.38 & $<1$ \\
\hline & $\begin{array}{l}\text { weath. } \\
\text { rock }\end{array}$ & 47 & 15 & & 1.2 & & 5 & & 4.4 & & 0.20 & $<20$ & 0.19 & $<20$ \\
\hline & unw. rock & 13 & 17 & & 0.2 & & 3.8 & & 2.7 & & -0.5 & $<10$ & 0.0 & $>50$ \\
\hline \multirow[t]{5}{*}{ clay / clay slate } & all & 73 & 32 & \multirow{5}{*}{67.5} & 1.7 & \multirow{5}{*}{21} & 6 & \multirow{5}{*}{3.1} & 15.9 & \multirow{5}{*}{26.9} & 0.79 & $<1$ & 0.74 & $<1$ \\
\hline & topsoil & 13 & 189 & & 8.4 & & 7.5 & & 24.2 & & 0.86 & $<1$ & 0.66 & $<2$ \\
\hline & subsoil & 39 & 26 & & 1.3 & & 6 & & 23.5 & & 0.53 & $<1$ & 0.59 & $<1$ \\
\hline & $\begin{array}{l}\text { weath. } \\
\text { rock }\end{array}$ & 15 & 15 & & 0.8 & & 4.4 & & 7.7 & & 0.91 & $<1$ & 0.85 & $<1$ \\
\hline & unw. rock & 6 & 2.8 & & 0.4 & & 2.4 & & 0.9 & & 0.75 & $<10$ & 0.82 & $<5$ \\
\hline \multirow[t]{5}{*}{ phyllite } & all & 21 & 58 & \multirow{5}{*}{66.5} & 3.5 & \multirow{5}{*}{357} & 8 & & 10.9 & \multirow{5}{*}{1.9} & 0.6 & $<1$ & 0.61 & $<<1$ \\
\hline & topsoil & 2 & 1264 & & 107 & & 10 & 3.2 & 20.7 & & - & & - & - \\
\hline & subsoil & 14 & 112 & & 7.9 & & 8 & & 10 & & 0.40 & $<20$ & 0.29 & $>20$ \\
\hline & weath. & 4 & 8.2 & & 0.6 & & 2.9 & & 6.5 & & -0.09 & & -0.5 & $>20$ \\
\hline & unw. rock & 1 & 19 & & 0.3 & & 3.1 & & 10.9 & & - & & - & - \\
\hline
\end{tabular}


sandstone

\begin{tabular}{cc||c} 
all & 19 \\
topsoil & 7 & 171 \\
subsoil & 7 & \\
weath. & 4 \\
rock & 1 & \\
unw. rock & 1.5
\end{tabular}

$\begin{array}{rl}25 & \\ 171 & 155 \\ 23 & \\ 9.5 & \\ 1.1 & \end{array}$

$155 \mid$\begin{tabular}{l|l}
1.2 \\
7.1 \\
1.2 \\
0.7
\end{tabular}

1.2
7.1
1.2
0.7
0.2

$36 \mid \begin{array}{rr}8 & \\ 9 & 2.4 \\ 8 & \\ 6.3 & \\ 3.8 & \end{array}$

\begin{tabular}{r|r}
14.9 \\
20 \\
15. \\
5.7 \\
0.6
\end{tabular}

$33.3 \|$

\begin{tabular}{rr||}
0.26 & $>20$ \\
-0.4 & $>20$ \\
0.34 & $>20$ \\
-0.07 & $>50$ \\
- & $>20$
\end{tabular}

$0.03>50$

$-0.34>20$

$0.35>20$

$-0.29>50$ 


\section{Captions}

Fig. 1: Correlation of colour determination by two individual observers: linear regression (solid) and unity line (dashed).

Fig. 2: Low frequency magnetic susceptibility $\chi_{\mathrm{LF}}$, frequency-dependent susceptibility $\Delta \chi$, redness rating and $\mathrm{Fe}$ content of the investigated samples. The samples are grouped according to their parent material and the groups are further subdivided into subgroups of unweathered rock, weathered rock, subsoil and topsoil (from left to right). The black dots inside the white circles represent the medians, while the boxes represent the lower and upper quartiles. The whiskers denote the most extreme values within the interval of the first quartile minus, and the third quartile plus 1.5 times the interquartile range, respectively. These correspond to a roughly $99 \%$ coverage of the data. Outliers with values beyond the ends of the whiskers are displayed as circles.

Fig. 3: Correlation between the logarithm of LF susceptibility and redness rating. Grouping is according to parent rock types and the number of samples is given in parentheses. The correlation coefficient $r$ and the regression line is given for the entire groups without differentiating between different degree of weathering and the dashed line delineates $95 \%$ confidence bounds.

Fig. 4: Correlation between the logarithm of frequency-dependent susceptibility and redness rating. Grouping is according to parent rock types and the number of samples is given in parentheses. The correlation coefficient $r$ and the regression line are given for the entire groups without differentiating between different degree of weathering and the dashed line delineates $95 \%$ confidence bounds. 
Figures

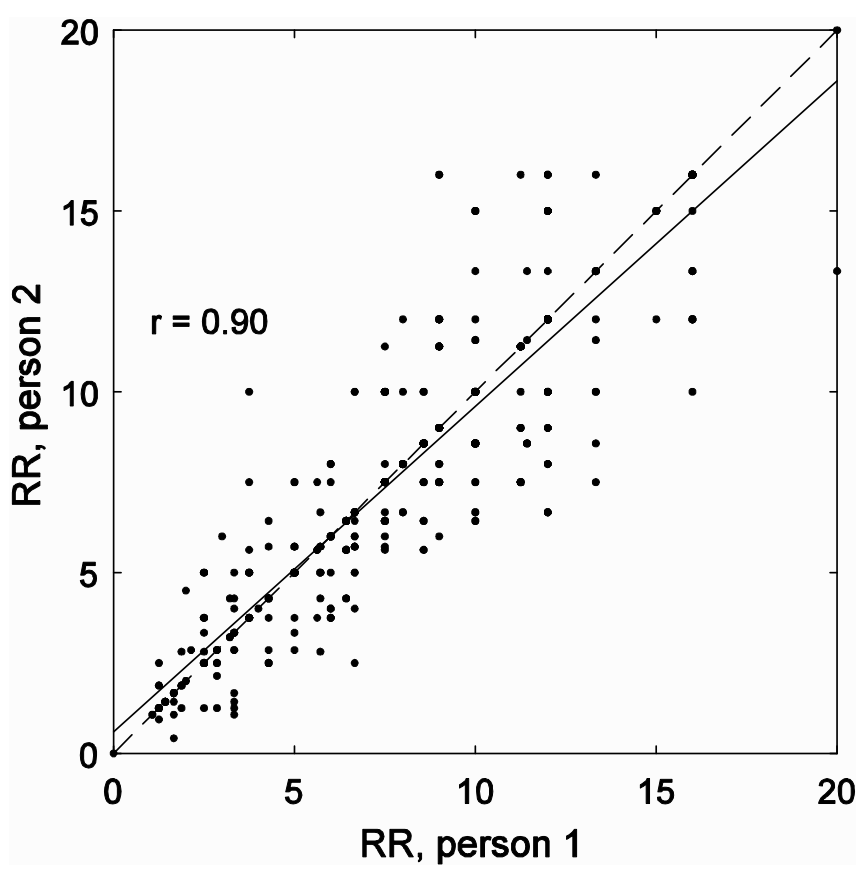

Fig. 1: Fig01_RR1vsRR2.eps 

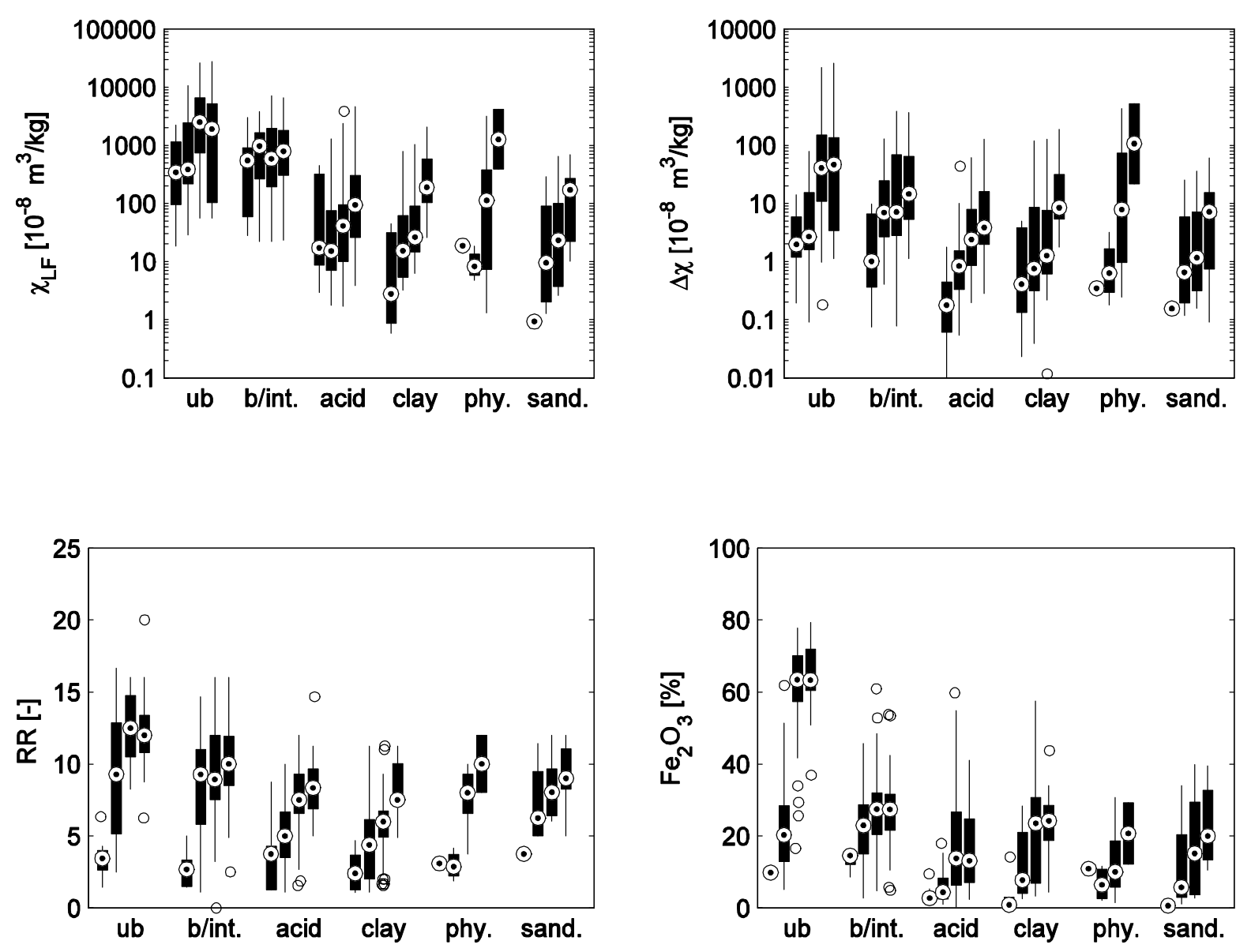

Fig. 2: Fig2_Boxplots_chiLF_chiFD_RR_Fe.eps 

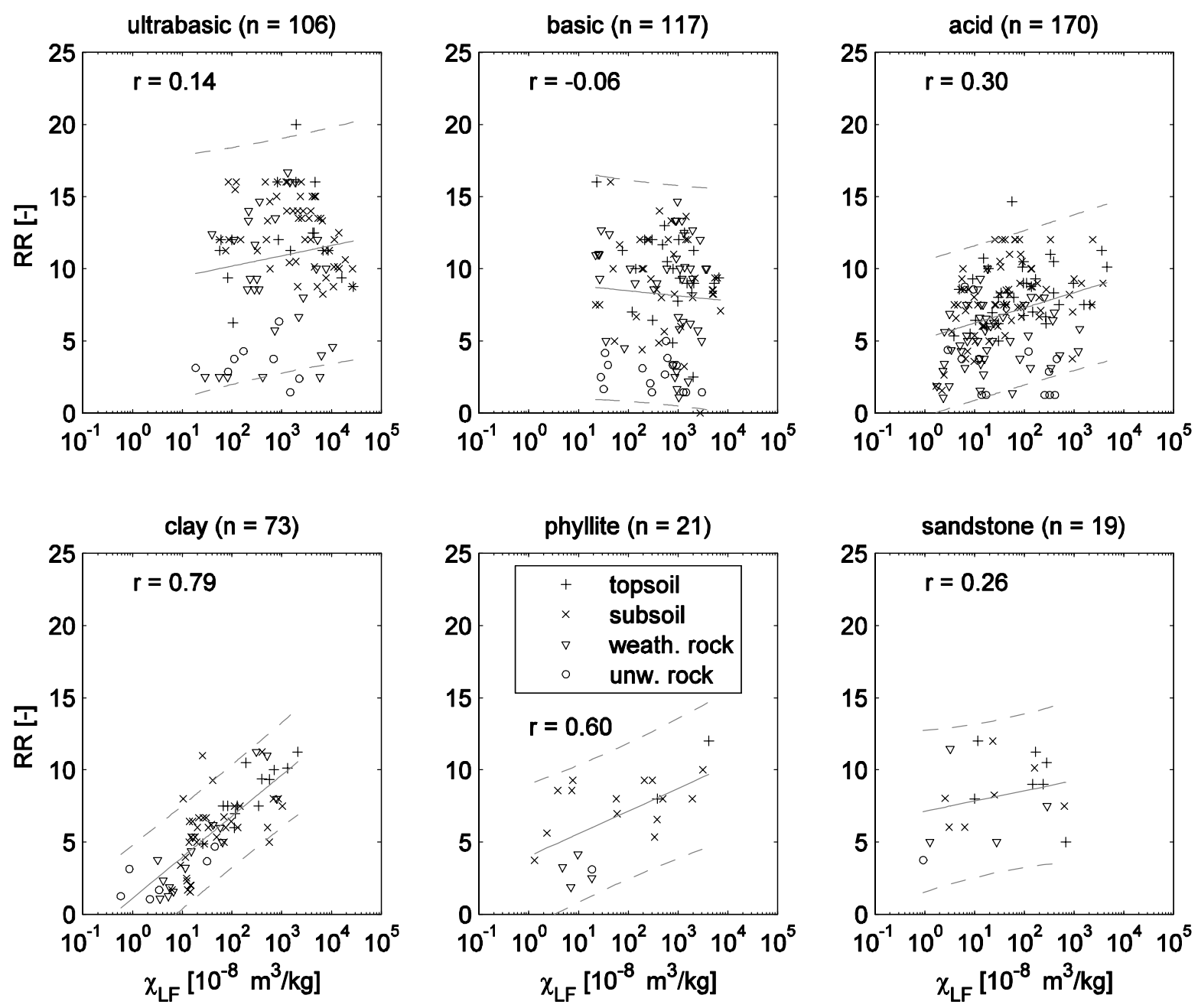

Fig. 3: Fig3_Scatter_RR_chiLF.eps 

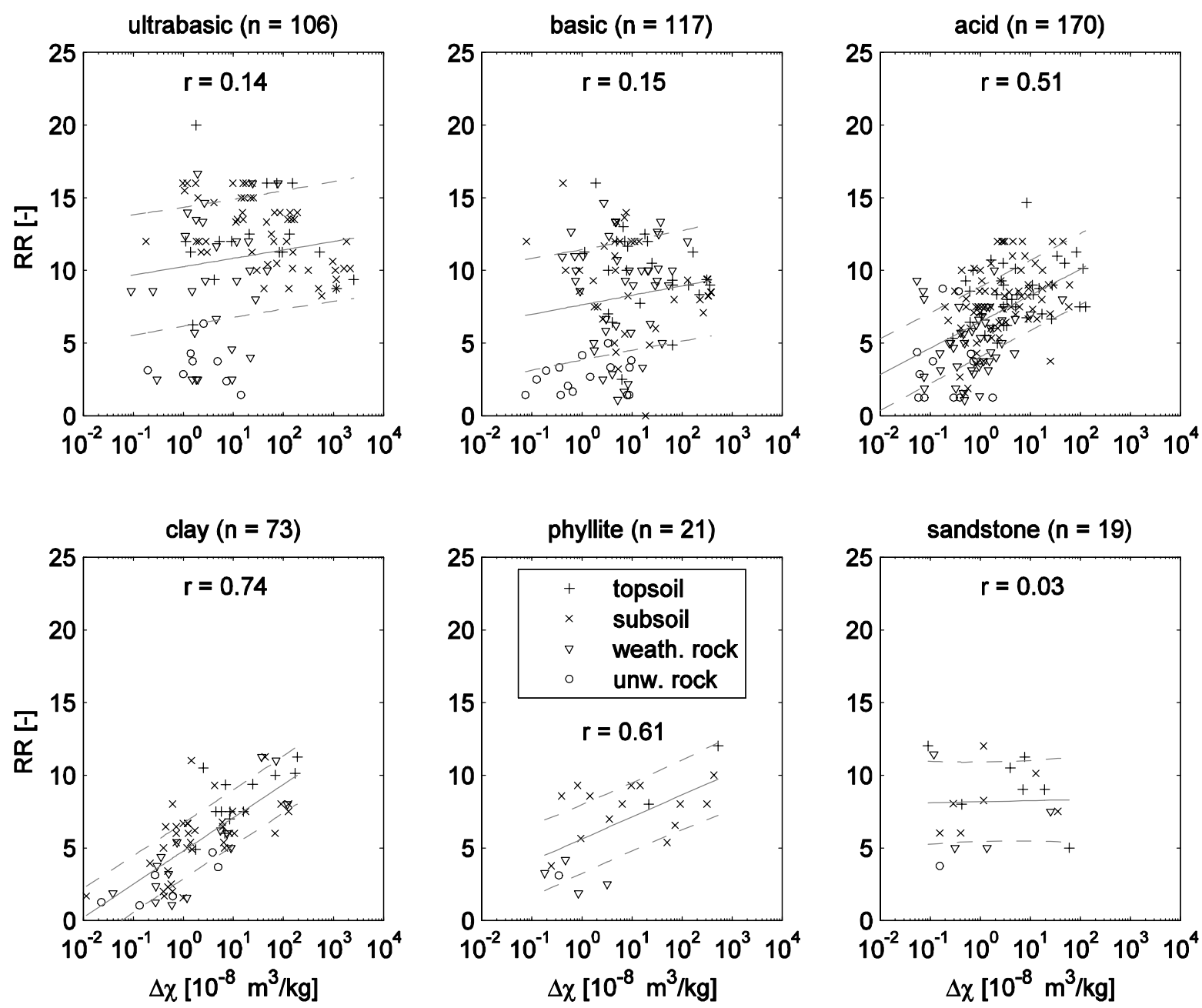

Fig. 4: Fig4_Scatter_RR_chiFD.eps 